\title{
Effect of sulphur and oxygen fugacity on vapour-saturation pressure calculations
}

\author{
ERY HUGHES ${ }^{1}$, PHILIPPA LIGGINS ${ }^{2}$, LEE SAPER $^{1}$ AND \\ EDWARD STOLPER ${ }^{1}$ \\ ${ }^{1}$ Caltech \\ ${ }^{2}$ University of Cambridge \\ Presenting Author: ehughes@caltech.edu
}

Dissolved $\mathrm{H}_{2} \mathrm{O}$ and $\mathrm{CO}_{2}$ concentrations in silicate glass are often used to calculate the entrapment pressure of a melt inclusion, eruption pressure of matrix glass, and composition of a vapour bubble in a melt inclusion. Currently available programs to calculate the pressure of vapour-saturation $\left(P_{\text {sat }}^{\mathrm{v}}\right)$ and coexisting vapour composition from measured concentrations of dissolved volatiles in melts/glasses (e.g., VolatileCalc, MagmaSat, VESIcal, etc.) assume the vapour contains only $\mathrm{H}_{2} \mathrm{O}$ and $\mathrm{CO}_{2}$, neglecting the role of sulphur- and other hydrogen- and carbon-bearing species in the vapour. We have developed a thermodynamic model where the melt contains $\mathrm{H}_{2} \mathrm{O}_{\text {mol }}, \mathrm{OH}^{-}$, $\mathrm{CO}_{2, \text { mol }}, \mathrm{CO}_{3}^{2-}, \mathrm{S}^{2-}$, and $\mathrm{SO}_{4}^{2-}$; and the vapour contains $\mathrm{O}_{2}, \mathrm{H}_{2}$, $\mathrm{H}_{2} \mathrm{O}, \mathrm{CO}, \mathrm{CO}_{2}, \mathrm{CH}_{4}, \mathrm{~S}_{2}, \mathrm{SO}_{2}, \mathrm{H}_{2} \mathrm{~S}$, and OCS. The pressure at which the sum of the partial pressures of all the vapour species equals the total pressure is $P_{\text {sat }}^{\mathrm{v}}$, and the vapour composition is given by the partial pressures of the vapour species. The fugacities of $\mathrm{CO}_{2}\left(f_{\mathrm{CO} 2}\right)$ and $\mathrm{H}_{2} \mathrm{O}\left(f_{\mathrm{H} 2 \mathrm{O}}\right)$ are calculated from dissolved $\mathrm{H}_{2} \mathrm{O}_{\text {mol }}$ and $\mathrm{CO}_{3}{ }^{2-}$ concentrations using known solubility functions. We use the concepts of sulphide and sulphate capacity which, given $f_{\mathrm{O} 2}$ (e.g., from $\mathrm{Fe}^{3+} / \mathrm{Fe}^{2+}$ or $\left.\mathrm{S}^{6+} / \mathrm{S}^{2-}\right)$ and the total dissolved sulphur $\left(\mathrm{S}_{\mathrm{T}}\right)$, are used to solve for $f_{\mathrm{S} 2}$. Given these fugacities $\left(f_{\mathrm{CO} 2}, f_{\mathrm{H} 2 \mathrm{O}}, f_{\mathrm{O} 2}\right.$, and $\left.f_{\mathrm{S} 2}\right)$, we calculate $f_{\mathrm{H} 2}, f_{\mathrm{CO}}, f_{\mathrm{SO} 2}, f_{\mathrm{CH} 4}, f_{\mathrm{H} 2 \mathrm{~S}}$, and $f_{\mathrm{OCS}}$ as a function of total pressure. Fugacities of all vapour species are converted to partial pressures and mole fractions (i.e., vapour composition) at a given pressure using fugacity coefficient functions. For the same dissolved $\mathrm{H}_{2} \mathrm{O}$ and $\mathrm{CO}_{2}$ in the melt: (1) Including additional vapour species increases calculated $P_{\text {sat }}^{\mathrm{v}}$ - hence, previous estimates of $P_{\text {sat }}^{\mathrm{v}}$ represent minima. This also applies to our results as we have not included $\mathrm{Cl}, \mathrm{F}, \mathrm{N}$, etc. -bearing species, but their contributions to total pressure are typically smaller than S-bearing species. And (2) decreasing melt $f_{\mathrm{O} 2}$ increases the calculated $P_{\text {sat }}^{\mathrm{v}}$ because the proportion of species such as $\mathrm{H}_{2}$ and $\mathrm{CO}$ increases in the vapour. Additionally, we show how bounds on $f_{\mathrm{O} 2}$ are obtained by comparing $\mathrm{S}_{\mathrm{T}}$ to the sulphide content at sulphide saturation and/or sulphate content at anhydrite saturation. 